DOI : https://doi.org/10.24843/JFU.2020.v09.i02.p06

pISSN: 2301-7716; eISSN: 2622-4607

Jurnal Farmasi Udayana, Vol 9, No 2, Tahun 2020, 110-122

\title{
Perbandingan Stabilitas Obat Racikan yang Dipreparasi Menggunakan Mortir dan Tablet Crusher di Apotek Sarana Pelayanan Kesehatan Primer
}

\author{
Widiasmini, N.P.E. ${ }^{1}$, Jaya, M.K.A ${ }^{2 *}$, Santika, I.W.M ${ }^{2}$ \\ ${ }^{1}$ Program Studi Farmasi Klinis Institut Ilmu Kesehatan Medika Persada Bali, Jalan Seroja, Gang Jeruk, \\ Denpasar, 80234 \\ ${ }^{2}$ Program Studi Farmasi, Fakultas Matematika dan Ilmu Pengetahuan Alam, Universitas Udayana, Jalan \\ Kampus Unud, Jimbaran, 80364 \\ *E-mail: krisnaadijaya@unud.ac.id
}

Riwayat artikel: Dikirim: 30/06/2020; Diterima: 17/11/2020, Diterbitkan: 27/12/2020

\begin{abstract}
Background: Drugs crushed using mortar is indeed already assessed according the procedure and maintained stability of the cure. But this process requires a relatively long that made some pharmacies preparing medications using a tablet crusher machine. There is a possibility of crushed using a tablet crusher will reduce the stability of certain types of drugs if direct contact with the metal blender machine. Purpose: The variable examined was the stability of the region, namely drug comparison of levels of a drug that dipreparasi uses a tablet crusher and mortar in the primary health care facility pharmacies. Methods: UV-VIS spectrophotometry. Results: The maximum wavelength of klorfeniramine maleate acquired was $261.5 \mathrm{~nm}$ and paracetamol is $247.7 \mathrm{~nm}$. \% recovery of klorfeniramine maleate raw is $\pm 2.8 \%$ whereas 99.82 on paracetamol is $2.09 \% \pm 100.17$. The result of the calculation precision value was obtained by tests at on klorfeniramine maleate is $0.76 \%$ whereas on paracetamol is $1.13 \%$. LOD and LOQ of klorfeniramine maleate is $3.20 \pm 0.05$ and $0.15 \pm 9.7$ while the LOD and LOQ of paracetamol is $0.38 \pm 0.22$ and $1.16 \pm 0.56$. Preparation of comparative test results time crushed with a levels has been made aware that the value of significance test of the Mann Whitney absence of difference levels of drugs that are dipreparasi using mortars and tablet crusher. Conclusion: Drug Crushed with tablet crusher and with mortar does not have the difference.
\end{abstract}

Keyword: blender, crusher, mortars, stability

\begin{abstract}
ABSTRAK
Latar Belakang: Penggerusan obat dengan menggunakan mortir memang dinilai sudah sesuai prosedur dan dapat terjaga stabilitas obatnya. Tetapi proses ini membutuhkan waktu yang relatif lama sehingga membuat beberapa apotek meracik obat dengan menggunakan mesin tablet crusher. Ada kemungkinan penggerusan menggunakan tablet crusher akan mengurangi stabilitas jenis obat tertentu jika kontak langsung dengan logam mesin blender. Tujuan: variable yang diteliti adalah stabilitas obat racikan yaitu perbandingan kadar suatu obat yang dipreparasi menggunakan tablet crusher dan mortir di apotek sarana pelayanan kesehatan primer. Metode: Spektrofotometri UV-VIS. Hasil: Panjang gelombang maksimum klorfeniramine maleat yang diperoleh adalah 261,5 $\mathrm{nm}$ dan parasetamol adalah $247,7 \mathrm{~nm}$. \% perolehan kembali (\% recovery) baku klorfeniramin maleat adalah $99,82 \pm 2,8 \%$ sedangkan pada parasetamol adalah $100,17 \pm 2,09 \%$. Hasil dari perhitungan uji presisi didapatkan nilai RSD pada klorfeniramin Maleat adalah 0,76\% sedangkan pada parasetamol adalah 1,13\%. LOD dan LOQ dari klorfeniramin maleat adalah 3,20 $\pm 0,05$ dan 9,7 $\pm 0,15$ sedangkan LOD dan LOQ dari parasetamol adalah $0,38 \pm 0,22$ dan 1,16 $\pm 0,56$. Hasil pengujian perbandingan preparasi waktu penggerusan dengan kadar yang telah dilakukan diketahui bahwa nilai signifikansi uji Mann Whitney tidak adanya perbedaan kadar obat yang dipreparasi dengan menggunakan mortir dan tablet crusher. Kesimpulan: Penggerusan obat dengan tablet crusher dan dengan mortir tidak memiliki perbedaan secara statistik.
\end{abstract}

Kata Kunci : blender, crusher, mortir, stabilitas 


\section{Widiasmini, dkk.}

DOI : https://doi.org/10.24843/JFU.2020.v09.i02.p06

pISSN: 2301-7716; eISSN: 2622-4607

Jurnal Farmasi Udayana, Vol 9, No 2, Tahun 2020, 110-122

\section{PENDAHULUAN}

Jaminan Kesehatan Nasional (JKN) yang diselenggarakan oleh suatu Badan Penyelenggara Jaminan Sosial (BPJS) diberikan oleh pemerintah Indonesia kepaada warga negara Indonesia untuk meringankan beban masyarakat terkait masalah kesehatan. JKN meliputi semua fasilitas kesehatan yang bekerjasama dengan BPJS Kesehatan. Berdasarkan Peraturan Menteri Kesehatan Nomor 71 Tahun 2013 tentang pelayanan kesehatan pada Jaminan Kesehatan Nasional, pelayanan kesehatan bagi peserta BPJS dilaksanakan secara berjenjang sesuai kebutuhan medis dimulai dari fasilitas kesehatan tingkat I (Permenkes RI, 2013). Munculnya peraturan ini menyebabkan terjadinya peningkatan jumlah pasien yang menerima pelayanan kesehatan di fasilitas kesehatan tingkat I yaitu di puskesmas. Pelayanan kefarmasian adalah pelayanan yang langsung bertanggung jawab kepada pasien. Salah satu kegiatan kefarmasian, seperti kegiatan pelayanan obat atas resep dokter (dispensing obat) (Permenkes RI, 2016). Penyerahan obat ini merupakan masalah utama yang paling sering ditemukan karena lamanya waktu tunggu obat. Semakin lama waktu tunggu suatu pelayanan, akan menimbulkan persepsi negatif terhadap suatu proses produksi, kualitas pelayanan, dan kepuasan konsumen. Pasien yang datang ke sarana pelayanan kesehatan seperti puskesmas, pasti menginginkan suatu sistem pelayanan kesehatan yang baik dan berkualitas tanpa harus menunggu pelayanan dalam waktu yang lama (Jaya and Apsari, 2018).

Pelayanan resep racikan merupakan kegiatan yang memakan waktu tunggu yang cukup lama. Pelayanan resep racikan ini dapat dilakukan secara manual dengan digerus di dalam mortir maupun dengan cara menggunakan alat milling yaitu dengan menggunakan tablet crusher (Blender). Penggerusan obat dengan menggunakan mortir memang dinilai sudah sesuai prosedur dan dapat terjaga stabilitas obatnya. Tetapi proses ini membutuhkan waktu yang relatif lama sehingga membuat beberapa apotek meracik obat dengan menggunakan mesin tablet crusher. Ada kemungkinan penggerusan menggunakan tablet crusher akan mengurangi stabilitas jenis obat tertentu jika kontak langsung dengan logam mesin blender dan menghasilkan panas yang berlebih (Cou, 2018).

Klorfeniramin maleat (CTM) dan parasetamol merupakan obat yang paling sering digunakan dalam peracikan obat (Widyaswari and Wiedyaningsih, 2012). Klorfeniramin maleat merupakan agen antihistamin yang digunakan untuk mencegah dari gejala alergi seperti rinitis dan urtikaria, ruam kulit, mata berair, bersin, flu yang disebabkan karena alergi sedangkan parasetamol obat analgesik (penahan rasa sakit atau nyeri) dan anti-piretik (penurun panas atau demam) yang aman. Laju penguraian parasetamol dan klorfeniramin maleat dalam dalam bentuk racikan bervariasi tergantung pada $\mathrm{pH}$ dan temperaturnya.

\section{BAHAN DAN METODE}

\subsection{Bahan Penelitian}

Bahan penelitian yang digunakan baku pembanding klorfeniramin maleat, baku pembanding parasetamol (BBPOM di Denpasar), etanol 96\%, dan aquades, parasetamol (PIM pharmaceuticals,), klorfeniramin maleat (Zenith Pharmaceuticals).

\subsection{Instrumen Penelitian}

Instrumen yang digunakan adalah spektrofotometer UV-Vis (UV-1800 Shimadzu). Instrumen lainnya adalah tablet crusher (Kertacu Wines Abadi), mortir dan stamper, timbangan, sendok tanduk dan seperangkat alat-alat gelas (pyrex dan iwaki) (gelas beker $50 \mathrm{ml}$ dan $100 \mathrm{ml}$, labu ukur $5 \mathrm{ml}, 10 \mathrm{ml} ; 25 \mathrm{ml} ; 50 \mathrm{ml}$, pipet ukur 1 $\mathrm{ml}, 2 \mathrm{ml}$, Ball filler, kertas perkamen, klip obat

\subsection{Prosedur Penelitian}

\subsubsection{Klorfeniramin Maleat \\ Pembuatan larutan baku klorfeniramin maleat:}

Serbuk ditimbang 2,5 $\mathrm{mg}$ dilarutkan dengan akuades dalam labu ukur hingga $25 \mathrm{ml}$, kemudian digojog. 


\section{Widiasmini, dkk.}

DOI : https://doi.org/10.24843/JFU.2020.v09.i02.p06

pISSN: 2301-7716; eISSN: 2622-4607

Jurnal Farmasi Udayana, Vol 9, No 2, Tahun 2020, 110-122

Penetapan panjang gelombang maksimum:

Larutan baku kerja klorfeniramin maleat dengan konsentrasi 30 ppm dibuat dengan cara memipet sebanyak $3 \mathrm{ml}$ dari larutan induk klorfeniramin maleat kemudian dimasukkan dalam labu ukur $10 \mathrm{ml}$. Dibaca absorbansi larutan dengan menggunakan spektrofotometer UV-Vis pada rentang 200 - $400 \mathrm{~nm}$. Dilakukan pengulangan sebanyak lima kali.

\section{Pembuatan kurva baku}

Larutan baku seri dengan konsentrasi 15 , 20, 25, 30 ppm sebanyak $10 \mathrm{ml}$. diukur serapan masing-masing konsentrasi pada panjang gelombang maksimum dengan menggunakan spektrofotometer UV-Vis. Dilakukan pengulangan sebanyak tiga kali.

\section{Penetapan kadar sampel}

Ditimbang sampel pulveres klorfeniramin maleat yang telah dipreparasi dengan menggunakan mortir dan stamper dan tablet crusher. Jumlah sampel yang dipreparasi dengan menggunakan mortir dan stamper dan tablet crusher masing-masing sebanyak 10 seri. Seri ini berdasarkan perbedaan waktu preparasi yaitu 30 , $60,90,120,150,180,210,240,270$, dan 300 detik. Kemudian masing-masing seri tersebut dibuat larutan sampel dengan konsentrasi 30 ppm kemudian dibaca absorbansinya pada panjang gelombang maksimum. Penetapan kadar dilakukan dengan pengulangan sebanyak 3 kali. Kemudian dilakukan uji stabilitas pada hari ke0,1 dan 2 .

\subsubsection{Validasi Metode}

\section{Uji akurasi}

Dari larutan induk Klorfeniramin Maleat 100 ppm dibuat larutan baku CTM dengan konsentrasi 15，20， 25，30 ppm. Diukur serapannya pada panjang gelombang maksimum. Hasil absorbansi digunakan untuk menghitung harga perolehan kembali (\%recovery). \% recovery yaitu perbandingan kadar CTM yang didapat dengan kadar CTM yang sebenarnya.

\section{Uji presisi}

Di ambil larutan baku induk Klorfeniramin Maleat sebanyak $2 \mathrm{ml}$, dimasukkan ke dalam labu ukur $5 \mathrm{ml}$ kemudian tambahkan akuades hingga tanda batas. Dibuat larutan yang sama sebanyak 3 replikasi, dibaca absorbansi masingmasing larutan dengan menggunakan Spektrofotomerti UV-Vis pada panjang gelombang maksimum.

\subsubsection{Parasetamol}

\section{Pembuatan Larutan Baku Parasetamol}

Serbuk ditimbang $1,25 \mathrm{mg}$ dilarutkan dengan etanol $96 \%$ di dalam gelas beker kemudian dimasukkan ke dalam labu ukur hingga $25 \mathrm{ml}$ dan digojog.

\section{Penetapan panjang gelombang maksimum}

Larutan standar parasetamol dengan konsentrasi 6 ppm dibuat dengan cara memipet sebanyak $61,2 \mathrm{ml}$ dari larutan induk parasetamol kemudian dimasukkan dalam labu ukur $10 \mathrm{ml}$. Larutan diencerkan dengan etanol sampai tanda batas, kemudian digojog. Larutan tersebut diukur pada rentang panjang gelombang antara 200-400 $\mathrm{nm}$.

\section{Pembuatan kurva baku}

Dibuat larutan baku dengan seri konsentrasi 2, 3, 4, 5, 6 ppm sebanyak $10 \mathrm{~mL}$. Larutan seri yang telah dibuat kemudian diukur serapan masing-masing konsentrasinya pada panjang gelombang maksimum yang diperoleh sebanyak 3 kali pembacaan.

\section{Penetapan Kadar Sampel}

Ditimbang sampel pulveres yang telah dipreparasi dengan menggunakan mortir dan stamper dan tablet crusher. Jumlah sampel yang dipreparasi dengan menggunakan mortir dan stamper dan tablet crusher masing-masing sebanyak 10 seri. Seri ini berdasarkan perbedaan waktu preparasi yaitu 30, 60, 90, 120, 150, 180, 210, 240, 270, 300 detik. Kemudian masingmasing seri tersebut dibuat larutan sampel dengan konsentrasi 4 ppm dengan pelarut etanol 96\%. kemudian dibaca absorbansinya pada panjang gelombang maksimum. Penetapan kadar 


\section{Widiasmini, dkk.}

DOI : https://doi.org/10.24843/JFU.2020.v09.i02.p06

pISSN: 2301-7716; eISSN: 2622-4607

Jurnal Farmasi Udayana, Vol 9, No 2, Tahun 2020, 110-122

dilakukan dengan pengulangan sebanyak 3 kali. Kemudian dilakukan uji stabilitas pada hari ke-0, 1 dan 2.

\section{Validasi Metode}

\section{Uji akurasi}

Dari larutan induk parasetamol $50 \mathrm{ppm}$ dibuat larutan baku parasetamol dengan konsentrasi 2, 3, 4, 5, 6 ppm. Diukur serapannya pada panjang gelombang maksimum. Hasil absorbansi digunakan untuk menghitung harga perolehan kembali (\%recovery). \% recovery yaitu perbandingan kadar parasetamol yang didapat dengan kadar parasetamol yang sebenarnya.

\section{Uji Presisi}

Dari larutan induk parasetamol $50 \mathrm{ppm}$ dibuat larutan baku dengan konsentrasi 4 ppm sebanyak $10 \mathrm{~mL}$. dilakukan pengulangan sebanyak 5 kali, dibaca absorbansi masingmasing larutan dengan menggunakan Spektrofotomerti UV-Vis pada panjang gelombang maksimum.

\subsubsection{Analisis Data}

Penetapan kadar ditentukan berdasarkan persamaan regresi linier:

$\mathrm{y}=\mathrm{bx}+\mathrm{a}$.

Batas deteksi (LOD) dan batas kuantitasi ( $L O Q)$. Batas deteksi dan Batas kuantifikasi dapat ditentukan dengan :

a. Batas deteksi (LOD):

Karena $\mathrm{k}=3,3$ atau 10, simpangan baku $(\mathrm{Sb})=$ Sy/x, maka:

$$
L O D=\frac{3,3 \mathrm{Sy} / \mathrm{x}}{b}
$$

b. Batas kuantitasi (LOQ)

Keterangan:

$$
L O Q=\frac{10 \mathrm{Sy} / \mathrm{x}}{b}
$$

Sy/x : simpangan baku residual

b : slope

(Asra et al., 2017)

\section{Akurasi}

Akurasi diukur sebagai banyaknya analit yang diperoleh kembali.

Persen perolehan kembali.

$$
\% \text { Recovery }=\frac{\text { Konsentrasi Terukur }}{\text { konsentrasi sebenarnya }} \times 100 \%
$$

\section{Presisi}

(Roosita, 2007)

Presisi dinyatakan dengan persen simpangan baku relatif (\% RSD) atau persen koefisien variasi.

$$
\% R S D=\frac{S D}{\bar{x}} \times 100 \%
$$

(Sayuthi and Kurniawati, 2017)

\subsubsection{Analisis statistik}

Analisis statistik dilakukan terhadap penetapan kadar, uji akurasi dan uji presisi dari metode absorbansi pada sampel dengan menggunakan SPSS 16.0 for windows dengan taraf signifikansi 5\% dengan menggunakan Mann Whitney.

\section{HASIL}

\subsection{Penentuan Panjang Gelombang Maksimum Pada Klorfeniramin Maleat dan Parasetamol:}

Penentuan panjang gelombang maksimum pada penelitan ini menggunakan spektrofotometer UV-VIS. Penentuan panjang gelombang maksimum ini dilakukan karena panjang gelombang suatu senyawa dapat berbeda bila ditentukan pada kondisi dan alat yang berbeda. Penentuan panjang gelombang maksimum pada penelitian ini pada rentang 200 - $400 \mathrm{~nm}$. Berikut merupakan hasil pengukuran panjang gelombang maksimum klorfeniramine maleat dan parasetamol.

Pada gambar 1 menunjukkan bahwa panjang gelombang maksimum klorfeniramine maleat yang diperoleh adalah 261,5 $\mathrm{nm}$. Sedangkan pada gambar 2 menunjukkan panjang gelombang maksimum parasertamol adalah $247,7 \mathrm{~nm}$. 
DOI : https://doi.org/10.24843/JFU.2020.v09.i02.p06

pISSN: 2301-7716; eISSN: 2622-4607

Jurnal Farmasi Udayana, Vol 9, No 2, Tahun 2020, 110-122

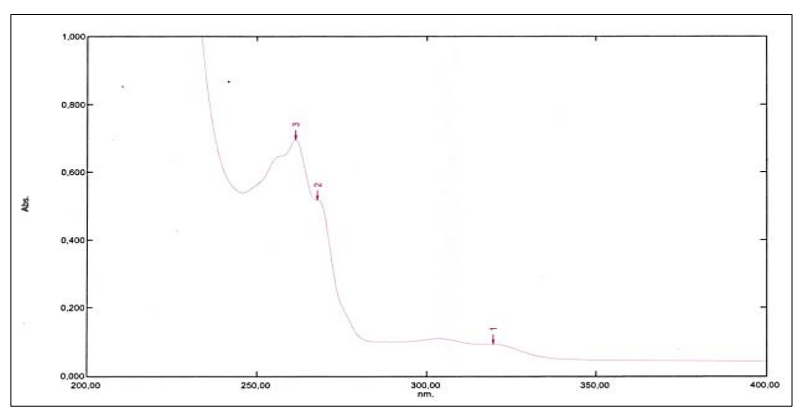

Gambar 1. Panjang Gelombang Maksimum Klorfeniramin Maleat

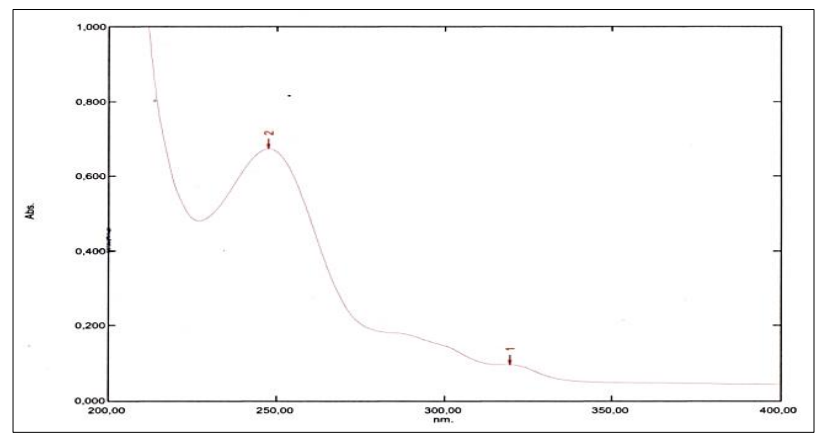

Gambar 2. Panjang Gelombang Maksimum Parasetamol

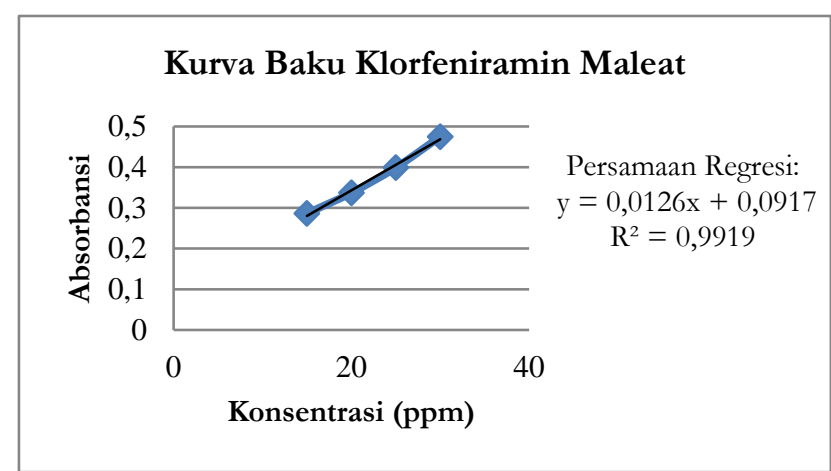

Gambar 3. Kurva Baku Klorfeniramin Maleat

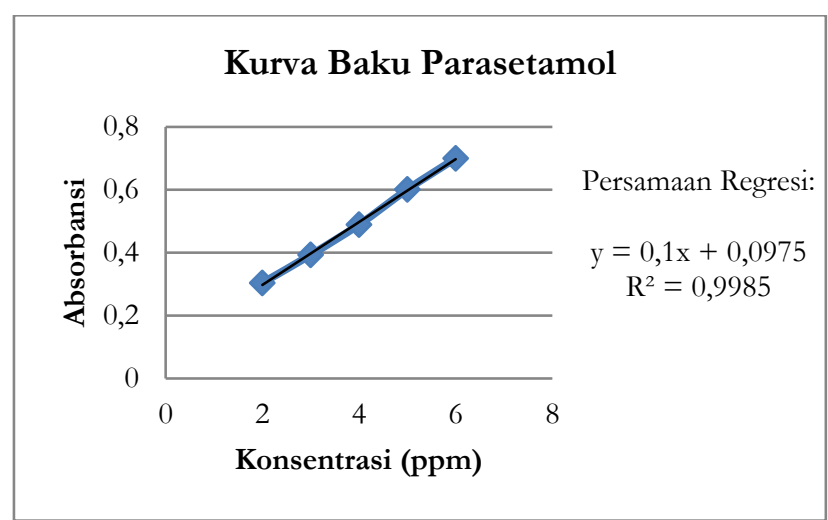

Gambar 4. Kurva Baku Parasetamol

\section{Kurva Baku}

Penentuan kurva baku dilakukan dengan menganalisis serangkaian konsentrasi larutan standar. Pada klorfeniramin maleat konsentrasi yang digunakan adalah 15, 20, 25, $30 \mathrm{ppm}$ sedangkan pada parasetamol konsentrasi larutan yang digunakan adalah 2, 3, 4, 5, 6 ppm.

Dari konsentrasi larutan klorfeniramin maleat yang telah dibuat diperoleh nilai $r^{2}=$ 0,9919 menggunakan persamaan linear $\mathrm{y}=$ 0,0126x + 0,0917 (Gambar 3). persamaan linear untuk larutan parasetamol adalah $\mathrm{y}=0,1 \mathrm{x}+$ 0,0975 (Gambar 4) dengan perolehan nilai $r^{2}=$ 0,998 .

\subsection{Validasi Metode}

\section{Akurasi}

Pada penelitian ini menggunakan uji akurasi dengan menggunakan baku pembanding dari persamaan regresi linier yaitu $(y=b x+a)$, dapat

ditentukan besarnya konsentrasi baku terukut (x) dengan memasukkan nilai serapan sebagai (y) dan ditentukan dengan $\%$ perolehan kembali $(\%$ recovery) sehingga dapat diperoleh $\%$ perolehan kembali baku klorfeniramin maleat adalah 99,79 $\pm 4,9 \%$ sedangkan pada parasetamol adalah $100,17 \pm 2,09 \%$. Hasil uji akurasi baku dapat dilihat pada tabel 1 dan tabel 2 .

\section{Presisi}

Pengujian penentuan presisi dilakukan dengan membaca absorbansi larutan pada konsentrasi 20 ppm pada klorfeniramin maleat dan 4 ppm pada parasetamol dengan 5 kali replikasi, Hasil dari perhitungan uji presisi didapatkan nilai RSD pada klorfeniramin Maleat adalah $0,76 \%$ sedangkan pada parasetamol adalah $1,13 \%$ Hasil uji presisi dapar dilihat pada table 3 dan 4.

\section{LOD dan LOQ}

Batas deteksi (LOD) dan batas kuantitasi (LOQ) yang diperoleh dari hasil pengujian klorfeniramin maleat dan parasetamol dapat dilihat pada table 5 . 
DOI : https://doi.org/10.24843/JFU.2020.v09.i02.p06

pISSN: 2301-7716; eISSN: 2622-4607

Jurnal Farmasi Udayana, Vol 9, No 2, Tahun 2020, 110-122

3.3 Penentuan Kadar Klorfeniramin Maleat dan Parasetamol

Penentuan kadar klorfeniramin maleat dilakukan dengan cara mengukur larutan sampel uji yang diduga mengandung klorfeniramin maleat pada panjang gelombang maksimum yaitu 261,5 nm. Hasil penentuan kadar klorfenirami maleat ditunjukan pada tabel 6.

Pada penentuan kadar parasetamol dilakukan pada panjang gelombang $247,7 \mathrm{~nm}$. Hasil penentuan kadar parasetamol ditunjukkan pada tabel 7.

Tabel 1. \% Perolehan Kembali (Recovery) Baku Klorfeniramin Maleat (CTM)

\begin{tabular}{|c|c|c|}
\hline Konsentrasi CTM Teoritis (ppm) & $\begin{array}{c}\text { Konsentrasi Rata-Rata CTM Terukur } \\
(\mathrm{ppm})\end{array}$ & \% Recovery Rata-Rata \\
\hline 15 & $15,45 \pm 1,2$ & $102,98 \pm 8,01$ \\
\hline 20 & $19,47 \pm 0,14$ & $97,34 \pm 0,69$ \\
\hline 25 & $24,39 \pm 0,27$ & $97,56 \pm 1,10$ \\
\hline 30 & $30,42 \pm 0,08$ & $101,40 \pm 0,26$ \\
\hline & $\bar{x} \pm \mathrm{SD}$ & $99,82 \pm 2,8$ \\
\hline
\end{tabular}

Tabel 2. \% Perolehan Kembali (Recovery) Baku Parasetamol

\begin{tabular}{|c|c|c|}
\hline $\begin{array}{c}\text { Konsentrasi Parasetamol Teoritis } \\
\text { (ppm) }\end{array}$ & $\begin{array}{c}\text { Konsentrasi Rata-Rata Parasetamol } \\
\text { Terukur (ppm) }\end{array}$ & \% Recovery Rata-Rata \\
\hline 2 & $2,07 \pm 0,2$ & $98,50 \pm 10$ \\
\hline 3 & $2,96 \pm 0,03$ & $97,96 \pm 1,0$ \\
\hline 4 & $3,92 \pm 0,06$ & $100,70 \pm 1,38$ \\
\hline 5 & $5,04 \pm 0,05$ & $100,42 \pm 1,04$ \\
\hline 6 & $6,03 \pm 0,08$ & $103,25 \pm 1,26$ \\
\hline & $\bar{x} \pm \mathrm{SD}$ & $100,17 \pm 2,09$ \\
\hline
\end{tabular}

Tabel 3. Hasil Perhitungan Presisi Klorfeniramine Maleat

\begin{tabular}{cc}
\hline Larutan & Konsentrasi (ppm) \\
\hline Replikasi 1 & 21,29 \\
Replikasi 2 & 21,07 \\
Replikasi 3 & 20,99 \\
Replikasi 4 & 21,37 \\
Replikasi 5 & 21,29 \\
\hline Rata-Rata & 21,20 \\
SD & 0,16 \\
\hline RSD & 0,76 \\
\hline
\end{tabular}

Tabel 4. Hasil Perhitungan Presisi Parasetamol

\begin{tabular}{cc}
\hline Larutan & Konsentrasi $(\mathrm{ppm})$ \\
\hline Replikasi 1 & 4,01 \\
Replikasi 2 & 3,99 \\
Replikasi 3 & 4,01 \\
Replikasi 4 & 4,09 \\
Replikasi 5 & 4,08 \\
\hline Rata-Rata & 4,03 \\
SD & 0,05 \\
\hline RSD & 1,13 \\
\hline
\end{tabular}

Tabel 5. Data Nilai LOD dan LOQ

$\begin{array}{lcc} & \text { Klorfeniramine Maleat } & \text { Parasetamol } \\ \text { LOD }(\text { Mean } \pm \text { SD) } & 3,20 \pm 0,05 & 0,38 \pm 0,22 \\ \text { LOQ (Mean } \pm \text { SD) } & 9,70 \pm 0,15 & 1,16 \pm 0,56\end{array}$


DOI : https://doi.org/10.24843/JFU.2020.v09.i02.p06

pISSN: 2301-7716; eISSN: 2622-4607

Jurnal Farmasi Udayana, Vol 9, No 2, Tahun 2020, 108-122

3.4 Hasil Analisis Perbandingan Waktu Penggerusan dengan Kadar Sampel

Pada penelitian ini dilakukan analisis data dengan menggunakan SPSS 16. Berdasarkan hasil analisis statistik yang dilakukan dengan uji mann whitney diperoleh nilai signifikansi ( $p>0,05)$. Hasil uji perbandingan sampel klorfeniramin maleat dapat dilihat pada tabel 8.

\section{PEMBAHASAN}

\subsection{Penentuan Panjang Gelombang Maksimum Pada Klorfeniramin Maleat dan Parasetamol}

Pada penelitian ini dilakukan penentuan panjang gelombang maksimum dengan menggunakan alat spektofotometer UV-Vis. Tujuan penentuan panjang gelombang maksimum ini, karena panjang gelombang suatu senyawa dapat berbeda bila ditentukan pada kondisi dan alat yang berbeda. Panjang gelombang maksimum ( $\lambda$ maks) merupakan panjang gelombang dimana terjadi eksitasi elektronik yang memberikan absorbansi maksimum. Tujuan dilakukan pengukuran pada panjang gelombang maksimum adalah perubahan absorbansi untuk setiap satuan kosentrasi adalah paling besar pada panjang gelombang maksimum, sehingga akan diperoleh kepekaan analisis yang maksimum. (Gandjar and Rohman, 2017)

Hasil pengukuran panjang gelombang maksimum pada klorfeniramin maleat adalah 261,5 sedangkan parasetamol adalah 247,7. Hasil tersebut menunjukkan absorbansi klorfeniramin maleat dan parasetamol masuk dalam rentang UV yaitu 200-400 nm, Secara teoritis panjang gelombang maksimum klorfeniramin maleat adalah $262 \mathrm{~nm}$ sedangkan untuk parasetamol adalah $245 \mathrm{~nm}$ (Moffat et al., 2011).

Tabel 6. Data Hasil Penentuan Kadar Klorfeniramin Maleat

\begin{tabular}{|c|c|c|c|c|c|}
\hline \multirow{2}{*}{ Perlakuan } & \multirow{2}{*}{ Lama Penggerusan (detik) } & \multirow{2}{*}{ Bobot Sampel (mg) } & \multicolumn{3}{|c|}{$\%$ Kadar Rerata dalam Tablet } \\
\hline & & & Hari Ke-0 & Hari Ke-1 & Hari Ke-2 \\
\hline \multirow{10}{*}{ Mortir } & 30 & 19,36 & 96,9 & 91,79 & 91,53 \\
\hline & 60 & 19,5 & 98,3 & 96,55 & 96,20 \\
\hline & 90 & 19,8 & 102,1 & 100,43 & 100,08 \\
\hline & 120 & 19,8 & 100,9 & 99,64 & 99,46 \\
\hline & 150 & 20 & 95,5 & 95,23 & 95,58 \\
\hline & 180 & 19,8 & 97,1 & 96,38 & 96,29 \\
\hline & 210 & 19,73 & 95,8 & 95,49 & 95,32 \\
\hline & 240 & 19,45 & 95,5 & 95,23 & 95,67 \\
\hline & 270 & 19,68 & 98,2 & 97,43 & 96,90 \\
\hline & 300 & 19,9 & 97,0 & 96,55 & 95,67 \\
\hline \multirow{10}{*}{$\begin{array}{l}\text { Tablet } \\
\text { crusher }\end{array}$} & 30 & 20 & 91,6 & 91,88 & 92,14 \\
\hline & 60 & 19,32 & 96,6 & 96,38 & 95,58 \\
\hline & 90 & 20 & 92,5 & 92,05 & 91,97 \\
\hline & 120 & 19,8 & 96,7 & 96,46 & 96,29 \\
\hline & 150 & 20 & 94,7 & 93,82 & 93,38 \\
\hline & 180 & 19,8 & 95,5 & 94,35 & 94,08 \\
\hline & 210 & 19,93 & 87,8 & 87,65 & 88,97 \\
\hline & 240 & 19,28 & 97,4 & 96,73 & 96,99 \\
\hline & 270 & 20 & 96,2 & 95,67 & 96,02 \\
\hline & 300 & 20,1 & 93,1 & 93,02 & 93,29 \\
\hline
\end{tabular}


Widiasmini, dkk.

DOI : https://doi.org/10.24843/JFU.2020.v09.i02.p06

pISSN: 2301-7716; eISSN: 2622-4607

Jurnal Farmasi Udayana, Vol 9, No 2, Tahun 2020, 108-122

Tabel 7. Data Hasil Penentuan Kadar Parasetamol

\begin{tabular}{|c|c|c|c|c|c|}
\hline \multirow{2}{*}{ Perlakuan } & \multirow{2}{*}{$\begin{array}{c}\text { Lama Penggerusan } \\
\text { (detik) }\end{array}$} & \multirow{2}{*}{$\begin{array}{l}\text { Bobot Sampel } \\
\quad(\mathrm{mg})\end{array}$} & \multicolumn{3}{|c|}{$\%$ Kadar Rerata dalam Tablet } \\
\hline & & & Hari Ke-0 & Hari Ke-1 & Hari Ke-2 \\
\hline \multirow{10}{*}{ Mortir } & 30 & 5,3 & 92,79 & 93,79 & 93,21 \\
\hline & 60 & 5,3 & 92,46 & 94,21 & 94,38 \\
\hline & 90 & 5,4 & 93,29 & 91,04 & 91,04 \\
\hline & 120 & 5,2 & 93,13 & 90,04 & 90,88 \\
\hline & 150 & 5,48 & 92,13 & 90,96 & 90,63 \\
\hline & 180 & 5,44 & 92,38 & 91,04 & 90,88 \\
\hline & 210 & 5,4 & 92,38 & 90,63 & 91,04 \\
\hline & 240 & 5,36 & 91,54 & 89,63 & 90,04 \\
\hline & 270 & 5,38 & 91,79 & 90,46 & 91,04 \\
\hline & 300 & 5,35 & 92,29 & 92,04 & 91,46 \\
\hline \multirow{10}{*}{ Tablet crusher } & 30 & 5,3 & 91,79 & 91,96 & 91,54 \\
\hline & 60 & 5,27 & 97,29 & 99,79 & 99,38 \\
\hline & 90 & 5,43 & 95,54 & 95,54 & 95,63 \\
\hline & 120 & 5,5 & 92,38 & 92,88 & 93,21 \\
\hline & 150 & 5,3 & 90,54 & 90,21 & 90,29 \\
\hline & 180 & 5,47 & 90,13 & 90,13 & 90,21 \\
\hline & 210 & 5,39 & 92,54 & 92,38 & 92,21 \\
\hline & 240 & 5,15 & 93,38 & 93,21 & 92,96 \\
\hline & 270 & 5,39 & 91,71 & 91,96 & 91,88 \\
\hline & 300 & 5,34 & 89,54 & 89,63 & 89,63 \\
\hline
\end{tabular}

Tabel 8. Hasil Uji Mann Whitney Perbandingan Preparasi Waktu Penggerusan dengan Kadar Tablet Hari Ke-0

\begin{tabular}{ccccc}
\hline \multirow{2}{*}{ Sampel } & Waktu & \multicolumn{2}{c}{$\%$ Kadar Tablet (Mean \pm SD) } & P Value \\
\cline { 3 - 4 }$($ detik) & Mortir & Crusher & $\mathrm{p}=0,700$ \\
& 30 & $96,9 \pm 9,2$ & $91,6 \pm 0,9$ & $\mathrm{p}=0,700$ \\
& 60 & $98,3 \pm 7,5$ & $96,6 \pm 1,9$ & $\mathrm{p}=0,200$ \\
Klorfeniramin Maleat & 90 & $102,1 \pm 12,3$ & $92,5 \pm 1,8$ & $\mathrm{p}=0,700$ \\
& 120 & $100,9 \pm 4,9$ & $96,7 \pm 0,7$ & $\mathrm{p}=0,700$ \\
& 150 & $95,5 \pm 1,6$ & $94,7 \pm 1,0$ & $\mathrm{p}=0,200$ \\
& 180 & $97,1 \pm 1,2$ & $95,5 \pm 1,3$ & $\mathrm{p}=0,100$ \\
& 210 & $95,8 \pm 1,9$ & $87,8 \pm 0,6$ & $\mathrm{p}=0,100$ \\
& 240 & $95,5 \pm 0,8$ & $97,4 \pm 0,8$ & $\mathrm{p}=0,700$ \\
& 270 & $98,2 \pm 3,7$ & $96,2 \pm 2,0$ & $\mathrm{p}=0,100$ \\
\hline
\end{tabular}

Tabel 9. Hasil Uji Mann Whitney Perbandingan Preparasi Waktu Penggerusan dengan Kadar Tablet Hari Ke-1

\begin{tabular}{ccccc}
\hline \multirow{2}{*}{ Sampel } & Waktu & \multicolumn{2}{c}{ \% Kadar Tablet (Mean \pm SD) } & P Value \\
\cline { 2 - 3 }$($ detik) & Mortir & Crusher & $\mathrm{p}=1,000$ \\
& 30 & $91,79 \pm 0,8$ & $91,88 \pm 1,2$ & $\mathrm{p}=1,000$ \\
& 60 & $96,55 \pm 1,9$ & $96,38 \pm 2,0$ & $\mathrm{p}=0,200$ \\
Klorfeniramin Maleat & 90 & $100,43 \pm 9,5$ & $92,05 \pm 1,5$ & $\mathrm{p}=0,100$ \\
& 120 & $99,64 \pm 2,8$ & $96,46 \pm 0,3$ & $\mathrm{p}=0,200$ \\
& 150 & $95,23 \pm 1,1$ & $93,82 \pm 1,2$ & $\mathrm{p}=0,100$ \\
& 180 & $96,38 \pm 1,1$ & $94,35 \pm 0,6$ & $\mathrm{p}=0,100$ \\
& 210 & $95,49 \pm 2,5$ & $87,65 \pm 1,0$ & $\mathrm{p}=0,100$ \\
& 240 & $95,23 \pm 0,9$ & $96,73 \pm 0,2$ & $\mathrm{p}=0,700$ \\
& 270 & $97,43 \pm 4,4$ & $95,67 \pm 0,9$ & $\mathrm{p}=0,100$ \\
\hline
\end{tabular}




\section{Widiasmini, dkk.}

DOI : https://doi.org/10.24843/JFU.2020.v09.i02.p06

pISSN: 2301-7716; eISSN: 2622-4607

Jurnal Farmasi Udayana, Vol 9, No 2, Tahun 2020, 108-122

Tabel 10. Hasil Uji Mann Whitney Perbandingan Preparasi Waktu Penggerusan dengan Kadar Tablet Hari Ke-2

\begin{tabular}{ccccc}
\hline \multirow{2}{*}{ Sampel } & Waktu & \multicolumn{2}{c}{ \% Kadar Tablet (Mean \pm SD) } & \multirow{2}{*}{ P Value } \\
\cline { 3 - 4 } & (detik) & Mortir & Crusher & $\mathrm{p}=0,700$ \\
& 30 & $91,53 \pm 0,7$ & $92,14 \pm 1,3$ & $\mathrm{p}=0,700$ \\
Klorfeniramin Maleat & 60 & $96,2 \pm 2,1$ & $95,58 \pm 2,3$ & $\mathrm{p}=0,200$ \\
& 90 & $100,08 \pm 9,4$ & $91,97 \pm 1,3$ & $\mathrm{p}=0,100$ \\
& 120 & $99,46 \pm 2,5$ & $96,29 \pm 0,4$ & $\mathrm{p}=0,200$ \\
& 150 & $95,58 \pm 1,0$ & $93,38 \pm 1,3$ & $\mathrm{p}=0,200$ \\
& 210 & $96,29 \pm 1,8$ & $94,08 \pm 1,3$ & $\mathrm{p}=0,100$ \\
& 240 & $95,32 \pm 2,8$ & $88,97 \pm 0,5$ & $\mathrm{p}=0,100$ \\
& 270 & $95,67 \pm 1,3$ & $96,99 \pm 0,2$ & $\mathrm{p}=1,000$ \\
& 300 & $96,9 \pm 4,1$ & $96,02 \pm 1,3$ & $\mathrm{p}=0,200$ \\
\hline
\end{tabular}

Tabel 11. Hasil Uji Mann Whitney Perbandingan Preparasi Waktu Penggerusan dengan Kadar Tablet Hari Ke-0

\begin{tabular}{ccccc}
\hline \multirow{2}{*}{ Sampel } & Waktu & \multicolumn{2}{c}{ \% Kadar Tablet (Mean \pm SD) } & \multirow{2}{*}{ P Value } \\
\cline { 3 - 4 } & (detik) & Mortir & Crusher & $\mathrm{p}=0,200$ \\
& 30 & $92,79 \pm 0,4$ & $91,79 \pm 0,8$ & $\mathrm{p}=0,100$ \\
& 60 & $92,46 \pm 1,0$ & $97,29 \pm 1,4$ & $\mathrm{p}=0,100$ \\
Parasetamol & 90 & $93,29 \pm 0,8$ & $95,54 \pm 0,8$ & $\mathrm{p}=0,100$ \\
& 120 & $93,13 \pm 0,9$ & $92,38 \pm 2,0$ & $\mathrm{p}=0,200$ \\
& 150 & $92,13 \pm 0,9$ & $90,54 \pm 1,3$ & $\mathrm{p}=0,100$ \\
& 180 & $92,38 \pm 0,7$ & $90,13 \pm 0,9$ & $\mathrm{p}=0,700$ \\
& 210 & $92,38 \pm 0,3$ & $92,54 \pm 0,8$ & $\mathrm{p}=0,100$ \\
& 240 & $91,54 \pm 0,8$ & $93,38 \pm 0,4$ & $\mathrm{p}=0,700$ \\
& 270 & $91,79 \pm 0,3$ & $91,71 \pm 0,4$ & $\mathrm{p}=0,100$ \\
\hline
\end{tabular}

Tabel 12. Hasil Uji Mann Whitney Perbandingan Preparasi Waktu Penggerusan dengan Kadar Tablet Hari Ke-1

\begin{tabular}{|c|c|c|c|c|}
\hline \multirow{2}{*}{ Sampel } & \multirow{2}{*}{$\begin{array}{l}\text { Waktu } \\
\text { (detik) }\end{array}$} & \multicolumn{2}{|c|}{$\%$ Kadar Tablet $($ Mean \pm SD) } & \multirow{2}{*}{ P Value } \\
\hline & & Mortir & Crusher & \\
\hline \multirow{10}{*}{ Parasetamol } & 30 & $93,79 \pm 1,2$ & $91,96 \pm 0,9$ & $\mathrm{p}=0,200$ \\
\hline & 60 & $94,21 \pm 0,9$ & $99,79 \pm 0,4$ & $\mathrm{p}=0,100$ \\
\hline & 90 & $91,04 \pm 0,5$ & $95,54 \pm 0,9$ & $\mathrm{p}=0,100$ \\
\hline & 120 & $90,04 \pm 0,7$ & $92,88 \pm 2,6$ & $\mathrm{p}=0,200$ \\
\hline & 150 & $90,96 \pm 0,6$ & $90,21 \pm 0,9$ & $\mathrm{p}=0,400$ \\
\hline & 180 & $91,04 \pm 0,5$ & $90,13 \pm 0,3$ & $\mathrm{p}=0,100$ \\
\hline & 210 & $90,63 \pm 0,7$ & $92,38 \pm 0,7$ & $\mathrm{p}=0,100$ \\
\hline & 240 & $89,63 \pm 0,3$ & $93,21 \pm 0,6$ & $\mathrm{p}=0,100$ \\
\hline & 270 & $90,46 \pm 0,5$ & $91,96 \pm 0,5$ & $\mathrm{p}=0,100$ \\
\hline & 300 & $92,04 \pm 0,8$ & $89,63 \pm 1,4$ & $\mathrm{p}=0,100$ \\
\hline
\end{tabular}


DOI : https://doi.org/10.24843/JFU.2020.v09.i02.p06

pISSN: 2301-7716; eISSN: 2622-4607

Jurnal Farmasi Udayana, Vol 9, No 2, Tahun 2020, 108-122

Tabel 13. Hasil Uji Mann Whitney Perbandingan Preparasi Waktu Penggerusan dengan Kadar Tablet Hari Ke-2

\begin{tabular}{|c|c|c|c|c|}
\hline \multirow{2}{*}{ Sampel } & \multirow{2}{*}{$\begin{array}{l}\text { Waktu } \\
\text { (detik) }\end{array}$} & \multicolumn{2}{|c|}{$\%$ Kadar Tablet (Mean \pm SD) } & \multirow{2}{*}{ P Value } \\
\hline & & Mortir & Crusher & \\
\hline \multirow{10}{*}{ Parasetamol } & 30 & $93,21 \pm 1,1$ & $91,54 \pm 0,3$ & $\mathrm{p}=0,100$ \\
\hline & 60 & $94,38 \pm 1,1$ & $99,38 \pm 0,3$ & $\mathrm{p}=0,100$ \\
\hline & 90 & $91,04 \pm 0,4$ & $95,63 \pm 1,1$ & $\mathrm{p}=0,100$ \\
\hline & 120 & $90,88 \pm 0,4$ & $93,21 \pm 2,5$ & $\mathrm{p}=0,700$ \\
\hline & 150 & $90,63 \pm 0,5$ & $90,29 \pm 1,3$ & $\mathrm{p}=1,000$ \\
\hline & 180 & $90,88 \pm 0,9$ & $90,21 \pm 0,5$ & $\mathrm{p}=0,400$ \\
\hline & 210 & $91,04 \pm 0,4$ & $92,21 \pm 0,8$ & $\mathrm{p}=0,100$ \\
\hline & 240 & $90,04 \pm 0,6$ & $92,96 \pm 0,6$ & $\mathrm{p}=0,100$ \\
\hline & 270 & $91,04 \pm 0,4$ & $91,88 \pm 0,3$ & $\mathrm{p}=0,100$ \\
\hline & 300 & $91,46 \pm 0,4$ & $89,63 \pm 1,5$ & $\mathrm{p}=0,100$ \\
\hline
\end{tabular}

Ketidaksesuaian ini dikarenakan adanya pergeseran pita penyerapan pada parasetamol. Pergeseran pita penyerapan tersebut karena pada struktur molekul parasetamol memiliki gugus auksokrom yang terikat pada gugus kromofor (Sayuthi and Kurniawati, 2017).

\subsection{Kurva Baku}

Penentuan kurva baku ini menunjukkan kemampuan suatu metode analisis untuk memperoleh hasil pengujian yang sesuai dengan konsentrasi analit dalam sampel pada kisaran konsentrasi tertentu. Kurva baku ini merupakan metode standar yang dapat digunakan untuk menentukan konsentrasi suatu analit berdasarkan hukum lambert-beer. Penentuan kurva baku ini dilakukan dengan menganalisis serangkaian konsentrasi larutan yang diukur pada panjang gelombang maksimum. Hasil pengukuran dari kurva ini adalah melalui persamaan garis lurus, dimana semakin besar konsentrasi larutan baku yang diukur maka semakin besar pula konsentrasi yang diperoleh.

Hal ini dikarenakan pada konsentrasi yang semakin tinggi, tingkat kepekatan senyawa semakin tinggi. Persamaan regresi klorfeniramin maleat adalah y $=0,0126 x+0,0917$ dengan nilai koefisien korelasinya (R) adalah 0,996 dan nilai koefisien determinasi $\left(\mathrm{R}^{2}\right)$ yang diperoleh adalah sebesar 0,9919 sedangkan persamaan regresi parasetamol adalah $\mathrm{y}=0,1 \mathrm{x}+0,0975$ dengan nilai koefisien korelasinya $(\mathrm{R})$ adalah 0,998 dan nilai koefisien deterinasi $\left(\mathrm{R}^{2}\right)$ yang diperoleh adalah sebesar 0,998. Kriteria nilai koefisien korelasi yaitu $\mathrm{R} \geq 0,995$ (Nerdy, 2017). Sehingga nilai korelasi yang di dapat sudah memenuhi kriteria. Nilai koefisien korelasi yang diperoleh tersebut merupakan hubungan antara konsentrasi larutan dengan absorbansinya sehingga persamaan garis tersebut dapat digunakan untuk menentukan validasi metode penentuan kadar dengan menggunakan spektrofotometer UV-Vis.

\subsection{Validasi Metode}

\section{Akurasi}

Akurasi (kecermatan) adalah ukuran yang menunjukkan derajat kedekatan hasil analis dengan kadar analit yang sebenarnya. Kecermatan dinyatakan sebagai persen perolehan kembali (recovery) analit yang ditambahkan, Nilai perolehan kembali (\%recovery) yang disyaratkan dalam range 80$110 \%$, sehingga dapat dikatakan metode ini memiliki akurasi yang dapat diterima. ${ }^{[9]} \%$ perolehan kembali (recovery) klorfeniramin maleat adalah 99,82 $\pm 2,8 \%$ sedangkan untuk parasetamol adalah 100,17 $\pm 2,09 \%$. Hasil \% perolehan kembali (recovery) kedua larutan tersebut sudah memenuhi kriteria yang disyaratkan,

\section{Presisi}

Presisi atau ketelitian adalah ukuran yang menunjukkan derajat kesesuaian antara hasil uji individual, diukur melalui penyebaran hasil individual dari rata-rata jika prosedur diterapkan secara berulang pada sampel-sampel yang diambil dari campuran yang homogen. Pada penelitian ini menggunakan metode repeatability. Repeatability adalah keseksamaan metode jika dilakukan berulang kali oleh analis 


\section{Widiasmini, dkk.}

DOI : https://doi.org/10.24843/JFU.2020.v09.i02.p06

pISSN: 2301-7716; eISSN: 2622-4607

Jurnal Farmasi Udayana, Vol 9, No 2, Tahun 2020, 108-122

yang sama pada kondisi sama dan dalam interval waktu yang singkat. Kriteria seksama diberikan jika metode memberikan nilai $\%$ RSD $\leq 2 \%$. Semakin kecil nilai standar deviasi yang diperoleh, maka makin kecil pula nilai koefisien variasinya (Sayuthi and Kurniawati, 2017).

Hasil penentuan presisi dari klorfeniramin maleat menunjukkan nilai standar deviasi yang diperoleh sebesar 0,16 dan nilai \% standar deviasi relatif (\%RSD) sebesar $0,76 \%$ sedangkan hasil penentuan presisi dari parasetamol menunjukkan nilai standar deviasi yang diperoleh sebesar 0,05 dan nilai $\%$ standar deviasi relatif (\%RSD) sebesar 1,13\%. Hasil yang diperoleh menunjukkan bahwa metode uji yang digunakan pada validasi metode penentuan kadar dalam sampel tablet obat dengan menggunakan spektrofotometri UV-Visible memenuhi syarat nilai \%RSD yang diterima.

\section{LOD dan LOQ}

Uji Limit of Detection (LOD) atau batas deteksi dilakukan untuk mengetahui jumlah atau konsentrasi terkecil analit dalam sampel yang dapat dideteksi, sedangkan uji Limit of Quantitation (LOQ) atau batas kuantitasi dilakukan untuk mengetahui jumlah analit terkecil dalam sampel yang dapat ditentukan secara kuantitatif pada tingkat ketelitian dan ketepatan yang baik. Batas kuantitasi merupakan parameter pengujian kuantitatif untuk konsentrasi analit yang rendah dalam matriks yang kompleks dan digunakan untuk menentukan adanya pengotor atau degradasi produk (Sayuthi and Kurniawati, 2017).

Hasil dari penentuan nilai LOD dan LOQ dari klorfeniramin maleat adalah 3,20 $\pm 0,05$ dan 9,7 $\pm 0,15$ sedangkan LOD dan LOQ dari parasetamol adalah $0,38 \pm 0,22$ dan 1,16 $\pm 0,56$. Berdasarkan hasil tersebut dapat diketahui bahwa nilai LOD yang diperoleh artinya pada kosentrasi tersebut masih dapat dilakukan pengukuran sampel yang memberikan hasil ketelitian suatu alat berdasarkan tingkat akurasi individual hasil analisis. Sedangkan, harga LOQ yang diperoleh artinya pada kosentrasi tersebut bila dilakukan pengukuran masih dapat memberikan kecermatan analisis.

\subsection{Penentuan Kadar Klorfeniramin Maleat dan Parasetamol}

Penentuan kadar klorfeniramin maleat dan parasetamol dilakukan dengan mengukur sampel uji yang telah dipreparasi dengan menggunakan mortir dan tablet crusher pada panjang gelombang maksimum dengan pengulangan sebanyak 3 kali. Penentuan kadar ini bertujuan untuk menjamin mutu serta keamanan suatu produk obat. Hasil rata-rata \% kadar tablet klorfeniramin maleat (tabel 5) dan parasetamol (tabel 6) yang diperoleh adalah 90-100\%. Menurut pernyaratan Farmakope Indonesia (FI) Edisi IV tahun 1995 bahwa besarnya kadar zat aktif senyawa obat dalam sebuah obat yaitu tidak kurang dari $90 \%$ dan tidak lebih dari $110 \%$. Hasil yang diperoleh dari hasil pengujian ini menunjukkan kesesuaian antara hasil pengujian dengan standar yang telah ditetapkan.

Profil kadar obat pada detik ke 180-210 pada klorfeniramin maleat dan parasetamol bahwa penggerusan dengan tablet crusher kemungkinan dapat menyebabkan stabilitas dari obat menurun meskipun dalam waktu selanjutnya terjadi peningkatan stabilitas. Stabilitas klofeniramin maleat dan parasetamol ini dipengaruhi oleh faktor-faktor antara lain suhu, kelembapan, cahaya pada saat penyimpanan wadah tertutup rapat dan tidak tembus cahaya (Kemenkes RI, 2014).

\subsection{Analisis Data Statistik Perbandingan Waktu Penggerusan dengan Kadar Sampel}

Berdasarkan hasil pengujian normalitas dari klorfeniramin maleat dan parasetamol, pada masing-masing kelompok data yang dapat dilihat pada lampiran 21 terdapat kelompok data yang nilai signifikansinya $<0,05$ sehingga data tersebut tidak terdistribusi normal. Hasil pengujian homogenitas dari klorfeniramin maleat terdapat kelompok data yang nilai signifikansi $<0,05$ sehingga data tidak homogen sedangkan pada parasetamol semua kelompok data memiliki nilai signifikansi $>0,05$ sehingga data homogen. Analisis data yang dilakukan pada 


\section{Widiasmini, dkk.}

DOI : https://doi.org/10.24843/JFU.2020.v09.i02.p06

pISSN: 2301-7716; eISSN: 2622-4607

Jurnal Farmasi Udayana, Vol 9, No 2, Tahun 2020, 108-122

penelitian ini adalah dengan uji non parametrik yaitu mann whitney. Hal ini karena syarat uji parametrik adalah data normalitas dan homogenitas harus normal sedangkan pada penelitian ini terdapat data yang tidak terdistribusi normal.

Berdasarkan hasil pengujian Mann Whitney diperoleh nilai signifikansi $>0,05$. Dasar pengambilan keputusan uji Mann Whitney yaitu jika nilai signifikansi $<0,05$ maka $\mathrm{H}_{0}$ ditolak, $\mathrm{Ha}$ diterima artinya ada perbedaan kadar obat yang digerus dengan menggunakan mortir dan menggunakan tablet crusher. Namun jika nilai signifikansi > 0,05 maka $\mathrm{H}_{0}$ diterima, Ha ditolak artinya tidak ada perbedaan kadar obat yang digerus dengan menggunakan mortir dan tablet crusher.

Hasil pengujian perbandingan preparasi waktu penggerusan dengan kadar yang telah dilakukan diketahui bahwa nilai signifikansi uji Mann Whitney $>0,05$, maka $\mathrm{H}_{0}$ diterima yang menunjukkan tidak adanya perbedaan kadar obat yang dipreparasi dengan menggunakan mortir dan tablet crusher. Tablet crusher dengan waktu penggerusan yang relatif cepat namun memiliki kemungkinan dapat mengurangi stabilitas jenis obat tertentu jika kontak langsung dengan logam mesin crusher dan menghasilkan panas dibandingkan dengan mortir yang memiliki waktu yang relatif lama dalam penggerusan, tidak memiliki perbedaan secara statistik

\section{KESIMPULAN}

Berdasarkan dari hasil penelitian yang telah dilakukan, dapat disimpulkan bahwa tidak ada perbedaan stabilitas obat yang dipreparasi dengan menggunakan mortir dan tablet crusher.

\section{UCAPAN TERIMAKASIH}

Terimakasih penulis ucapkan kepada seluruh staf dan dosen di lingkungan Prodi Farmasi Institut Ilmu Kesehatan Medika Persada Bali dan Prodi Farmasi, Fakultas MIPA, Universitas Udayana yang membantu penyelesaian penelitian ini.

\section{DAFTAR PUSTAKA}

1. Asra R, Rivai H, Astuty W. 2017. Pengembangan dan Validasi Metode Analisis Betametason Tablet dengan Metode Absorbansi dan Luas Daerah di Bawah Kurva Secara Spektrofotometri Ultraviolet. Jurnal Farmasi Higea.Vol 9(2):118-26.

2. Cou D. 2018. Perbedaan Kadar Parasetamol yang Digerus Menggunakan Mortir dan Menggunakan Blender dengan Metode Kromatografi Cair Kinerja Tinggi (KCKT). Jakarta: Medika Farma Husada.

3. Direktorat Jenderal Bina Kefarmasian dan Alat Kesehatan. 2014. Farmakope Indonesia Edisi V. Jakarta: Kementerian Kesehatan Republik Indonesia.

4. Gandjar IG, Rohman A. 2017. Kimia Farmasi Analisis. Yogyakarta: Pustaka Pelajar.

5. Jaya MKA, Apsari DP. 2018. Gambaran Waktu Tunggu dan Identifikasi Faktor Yang Mempengaruhi Lama Waktu Tunggu Pelayanan Obat Atas Resep Dokter Di Puskesmas Kota Denpasar. Jurnal Ilmiah Medicamento. Vol 4(2):95-99.

6. Nerdy N. 2017. Validation Of Ultraviolet Spectrophotometry Method For Determination Of Mefenamic Acid Level In Suspension Dosage Forms. Jurnal Natural. Vol 17(1):1-17.

7. Moffat AC, Osselton MD, Widdop B, Watts J, editors. 2011. Clarke's Analysis Of Drugs And Poisons: In Pharmaceuticals, Body Fluids And Postmortem Material. Fourth Edition. London; Chicago: Pharmaceutical Press.

8. Permenkes RI. 2013 Peraturan Menteri Kesehatan Republik Indonesia Nomor 71 Tahun 2013 Tentang Pelayanan Kesehatan Pada Jaminan Kesehatan Nasional. Jakarta: Kemenkes RI.

9. Permenkes RI. 2016. Peraturan Menteri Kesehatan Republik Indonesia Nomor 74 Tahun 2016 Tentang Standar Pelayanan Kefarmasian Di Puskesmas. Jakarta: Kemenkes RI. 
DOI : https://doi.org/10.24843/JFU.2020.v09.i02.p06

pISSN: 2301-7716; eISSN: 2622-4607

Jurnal Farmasi Udayana, Vol 9, No 2, Tahun 2020, 108-122

10. Roosita A. 2007. Validasi Metode Spektrofotometri Visibel untuk Penetapan Kadar Ampisilin Menggunakan Pereaksi Asetilaseton dan Formalin (Skripsi). Yogyakarta: Universitas Sanata Dharma.

11. Sayuthi MI, Kurniawati P. 2017. Validasi Metode Analisis Dan Penetapan Kadar Parasetamol Dalam Sediaan Tablet Secara Spektrofotometri Uv-Visible. Prociding. Yogyakarta: Universitas Islam Indonesia.

12. Widyaswari R, Wiedyaningsih C. 2012. Evaluasi Profil Peresepan Obat Racikan Dan Ketersediaan Formula Obat Untuk Anak Di Puskesmas Propinsi Diy. Majalah Farmasuetik. Vol. 8(3):1-10.

This work is licensed under a Creative Commons Attribution 4.0 International License 